$\begin{array}{ll} & \text { Etnográfica } \\ \text { etnográfica } & \text { Revista do Centro em Rede de Investigação em }\end{array}$

Antropologia

vol. $22(1) \mid 2018$

Vol. $22(1)$

\title{
Social anthropology and transnational studies in Latin America: introduction
}

Antropologia social e estudos transnacionais na América Latina: introdução

\section{Alejandro Grimson}

\section{(2) OpenEdition}

\section{Journals}

Electronic version

URL: https://journals.openedition.org/etnografica/5167

DOI: 10.4000/etnografica.5167

ISSN: 2182-2891

\section{Publisher}

Centro em Rede de Investigação em Antropologia

\section{Printed version}

Date of publication: 1 February 2018

Number of pages: 99-108

ISSN: 0873-6561

\section{Electronic reference}

Alejandro Grimson, "Social anthropology and transnational studies in Latin America: introduction", Etnográfica [Online], vol. 22 (1) | 2018, Online since 17 May 2018, connection on 21 January 2022. URL: http://journals.openedition.org/etnografica/5167 ; DOI: https://doi.org/10.4000/etnografica.5167

\section{(c) (i) (8)}

Etnográfica is licensed under a Creative Commons Attribution-NonCommercial 4.0 International License. 


\section{Social anthropology and transnational studies in Latin America: introduction}

\section{Alejandro Grimson}

The article analyzes the change of perspectives and narratives about national borders, the circulation of people and the political definitions of the limits of the National State in the social sciences since the fall of the Berlin Wall, in 1989, to the most recent outcomes of the international geopolitics. The place occupied by the transnational perspective of migration is questioned, inquiring its role in the formation of critical anthropological reflections that, in the last two decades, have allowed a re-oxygenation of the classical categories of analysis in the social sciences. The discussion also sediments the questioning about the possible outcomes of this anthropological reflection in a context of profound international political changes regarding human mobility.

KEYWORDS: trasnationalism, anthropology, globalization, migration, borders, Latin America.

Antropologia social e estudos transnacionais na América Latina: introdução - O artigo analisa a mudança de perspetivas e narrativas sobre as fronteiras nacionais, a circulação de pessoas e as definições políticas dos limites dos Estados nacionais nas ciências sociais desde a queda do Muro de Berlim, em 1989, até os desenlaces mais recentes da geopolítica internacional. Questiona-se, assim, o lugar ocupado pela perspetiva transnacional das migrações na formação de reflexões antropológicas críticas que, nas últimas duas décadas, permitiram uma reoxigenação das categorias clássicas de análise nas ciências sociais. A discussão sedimenta, ademais, o questionamento sobre os desenlaces possíveis desta reflexão antropológica num contexto de profundas transformações políticas internacionais no que se refere a mobilidade humana.

PALAVRAS-CHAVE: transnacionalismo, antropologia, globalização, migração, fronteiras, América Latina.

GRIMSON, Alejandro (agrimson@unsam.edu.ar) - National Council of Scientific and Technical Research of Argentina (Conicet); Institute for Higher Social Studies of the National University of San Martin (iDeAS-UNSAM), Argentina. 
After the fall of the Berlin Wall, a great narrative emerged. One that brought a trap, predicating the end of the great narratives. Nothing less than the End of History was announced. It was also announced that other "details" had expired too: ideologies, nations, states, borders. The list was extensive and the statement was overwhelming: 1989 did not inaugurate a new stage of history, but aimed to divide time into two. A historical stage that denied itself as such, as one more period with a beginning and an end. Thus, it was the beginning of a phase in which a broad and solid neoliberal consensus was imposed. This consensus stated that, no matter which party won the elections, the economic recipes would not propose real alternatives. After the 2008 crisis, an erosion of this neoliberal consensus accelerated, mainly because sectors of the society began to reject it.

That erosion was expressed in a growing political polarization in Europe and the United States. In the latter, it entailed an expansion of the radicalization of xenophobic, anti-immigrant and nationalist movements. These processes had two extraordinarily relevant triumphs in 2016: Brexit and Trump. Both are coup de grâce to globalization as we knew it. We can say that we are witnessing the end: the "end of history," the "end of nations," and the "end of borders."

The great narrative that we were heading towards an increasingly integrated world, with solid regional blocs, where nation-states would disappear and be replaced by regional citizenships was the dominant discourse at the end of the 1990s and persistent at the beginning of this century. It has declined in recent years. From now on, it is a directly absurd speech, meaningless, completely disconnected from political events. The world in which that great narrative was audible has ceased to exist.

In the 1990s, there was a momentary euphoria about the formation of a "world without borders." That is, without the sovereign regulation of nationstates over the territory. Needless to say that part of this enthusiasm was encouraged by the neoliberal conceptions of the economy, following an orthodoxy according to which states should be reduced to their minimum expression, even regarding the regulations of planetary flows and displacements. The curious fact is that these proposals emerged exactly 200 years after the beginning of the French Revolution (1789), a historic event that marks the "invention" of the nation-states and their political and administrative technology.

But the late $20^{\text {th }}$ century was also the scene of what Harvey (1989) once called the compression of the temporal experience of space. The spatial turn was boosted, at least in part, by the evidence regarding cheaper transportation costs and new communication technologies. We soon began to feel the world from unusual interconnections: to get to know geographically distant people and processes, but now linked by the myriads of technology. This set of global 
interconnections multiplied the planet's juxtapositions, asymmetries and disparities. It was, as Appadurai (1991) mentioned so many times, a simultaneous experience of junctions and disjunctions, forming a planetary process that soon became known as "globalization."

However, as the lyrics of an old Brazilian samba warn, sadness is infinite, but happiness always has an end. After the attacks of September 1 1, 2001 in New York, the world realized that the circulatory euphoria of globalization was short-lived. Or, at least, selective. It became increasingly evident that commodities and capital enjoy much more freedom of circulation than people. The geopolitics of the countries of the global north turned, gradually, towards a logic of militarized control that criminalizes the south-north migrations (and, increasingly, the subjects that carry them out). Thus, those migrant groups from the countries of the global south, from the periphery of the capitalist world, were configured in the imaginaries of the developed world as "unwanted invaders." Its marginality occurred, in parallel, as a phenomenon of identity representation, based on the intersections of the hegemonic hierarchies and classifications regarding ethnicity, religiosity, gender and nationality. Simultaneously, and contradictorily, this migrant labor became a fundamental piece in the great global cities of contemporary neoliberalism, those that Sassen (2010) incorporates into the "global classes" that, in their dynamics, disassemble the nation-state from the inside, and weaken the power of national politics over the particular groups that make them up.

Nevertheless, despite, and thanks to its contradictions, globalization was an era characterized by an increasing capacity for social imagination. In it, interpretative frameworks were challenged, impelling us to create new forms of understanding and, no less, new words that could credibly denominate nascent social phenomena. Thus, the oscillations between restrictions and circulatory freedoms of globalization caused, already at the beginning of the 1990s, a great confusion in the social sciences, leading to what many authors have called "the crisis of the great paradigms." With great frustration, sociologists, anthropologists and political scientists - among others - could testify the ineffectiveness of the great explanatory models, the classic paradigms that used to constitute identity coherers for researchers and social thinkers.

This confusion triggered various trends in the social sciences, but it would be excessive for our purposes to dwell on all of them in detail. We will limit ourselves to highlighting one aspect of these reflections that were catalyzed by globalization: the critical review on the classical argumentative insufficiencies in the social sciences. There are three central points we could highlight in this exercise.

The first refers to the criticism regarding the "methodological nationalisms." The social sciences, like all sciences, cannot investigate anything without presuppositions. Methodological nationalism is a very particular type of presupposition. Firstly, because the idea that the national space is the natural 
space where all the phenomena occur is not explicit. Due to that, surreptitiously, "society" becomes synonymous with "national society." The critique of methodological nationalism is a critique of an extensive stage of the social sciences in general. However, it became strong, precisely, in this period of transition from the $20^{\text {th }}$ to the $21^{\text {st }}$ century. It is not an exaggeration to suppose that this emergence was conditioned by the very transformation of social processes that cross borders in globalization.

The second refers to the transversal construction of a gender perspective towards phenomena that, like international migration, produce displacements of meaning, experience and materialities between nation-states. Until the end of the $20^{\text {th }}$ century, these phenomena were predominantly approached from androcentric perspectives, making the role of women invisible or, in recidivist cases, understanding their role as an accessory to that of men.

The third point refers to the questioning about the concept of "borders." Part of the studies on globalization were dedicated to contrasting the development of new transnational identifications to the crisis and the blurring of national identities. The debate was initially enunciated in terms of a "loss" of "tradition," being the latter ethnic or national. The circulatory euphoria of the beginnings of globalization influenced a curious tendency: that of assuming that national borders would be in process of extinction. Scholars of cross-border regions realized, already in the 1990s, that the symbolic, economic, political and military delimitations of nation-states not only remained, but acquired a central character in the global era. In the social sciences, these debates fostered the configuration of increasingly critical forms of categorization of borders. The national frontiers were theorized regarding the crossings, contradictions and $\mathrm{f}(\mathrm{r})$ ictions (Merenson 2016) they produce between subjects, cultures and histories. This debate has shown how the concept of border navigates between literal and metaphorical uses, becoming a key epistemic axis of social reflection and imagination (Guizardi et al. 2015).

In this scenario, certain social processes arouse more interest than others: international migration became a mandatory item on the study agenda of universities in the global north and south. Regarding that point, it may be convenient to establish some distinctions. It is amply demonstrated that the planet was populated not because one day human beings emerged simultaneously in one hundred parts of the globe, but through processes of displacement that lasted tens of thousands of years. If humans have been migratory beings throughout their history, why should they cease to be so in the present time? This demands another precision. What happens to obsess, worry and occupy the nation-states and the researchers in globalization are not all types of displacements, but specifically the one designated as international migration. That, as we said, cannot be understood as an old phenomenon, because the nation-states acquired their form recently, mostly in the $19^{\text {th }}$ and $20^{\text {th }}$ centuries. 
Then, the condition of existence of the international migration is that there are nations that name in this way the territorial displacements that cross their borders, their delimiting zones of territory, sovereignty and political community.

All the aspects indicated above served as coherers of the transnational perspective on migratory phenomena. This perspective questioned the conceptions regarding an abrupt separation between the localities of origin and destination of international migrants.

Although the concept of migratory transnationalism has been endowed with an interesting polysemy (Besserer 2004; Moctezuma 2008), it is possible to trace its initial definitions in the works of a group of researchers - Nina Glick Schiller, Peggy Levitt, Bela Feldman-Bianco, Cristina Blanc-Szanton, Linda Basch, Nina Sorensen - who studied Latin American migrations, usually in great urban centers of North America. Their debate was based on a collaboration between anthropologists and sociologists, which gave the initial studies a fruitful interdisciplinary character.

In an article that inaugurated this field of studies, Glick Schiller, Basch and Blanc-Szanton (1992) claim that in certain globalized spaces, the possibilities of technological interconnection with the localities of origin pushed the migrants to build migratory experiences according to innovative patterns: establishing familiar, economic, social, organizational and religious relationships in a multinational manner. This would cause the constant - simultaneous - connection between distant localities (Levitt and Glick Schiller 2004). This kind of linkage then produces a "transnational social field" articulated over national borders, which is structured through the relational networks woven between subjects and collectivities, and between "here" and "there" (Massey et al. 1993; Massey, Goldring and Durand 1994; Portes, Guarnizo and Haller 2002). These networks articulate the circulation of knowledge, cultural practices, economic resources (Portes 2000), constituting subjective and community trajectories through a transnationalized logic that produces, on several occasions, a non-literal experience of space (Besserer 2004). Migrant transnationalism, then, would be a form of "globalization from below" (Portes, Guarnizo and Landolt 1999; Portes 2003). Or, as Appadurai (1991) would say, "grassroots globalization."

Embracing a deep critique of methodological nationalism, transnational studies illuminate some of these international phenomena that involve the way people live their lives in and across borders to think about identifications, loyalties and memberships that strain the classical definitions of "community," "territory," "border," "identity" and "citizenship," among other key categories in social theory.

The emergence of new experiences and practices, associated with the relations of migrant and non-migrant actors with state and non-state institutions, both in the countries of origin and those of destination and transit, enabled a series of empirical, methodological and theoretical questions. These inquiries 
demonstrate the potentiality and, at the same time, the difficulties of the dialogue between social anthropology and transnational studies. Among the theoretical questions, it is worth mentioning central issues such as governance, development models, inequality, or the construction of new vocabularies of citizenship based on the cultural and political practices of the actors involved. Among those of a methodological nature, the design of multisited researches, the tensions between "context" and "displacement," between "articulation," "simultaneity" and "transnational flow." Thus, the transnational perspective had a critical effect that, even considering its limitations, fostered an oxygenation of the discipline's classic debates.

Nevertheless, 25 years after the beginning of theorizations about transnationalism in migratory studies, it is time to rethink the foundational aspects and the contemporary developments of this perspective. This critical review will make it easier for us to understand the limits and possibilities of the transnational perspective in the new post-global contexts, in which both the migratory flows and the social perception about them have changed incisively.

The present dossier hopes to contribute to this revision from particular proposals and guidelines that we detail below.

\section{THE ENCOUNTER}

The debates developed in the present dossier are also results of transnational and cross-border encounters between a group of researchers who, in different instances and in the last five years, are discussing their empirical data and their ethnographic inquiries in order to rethink the analytical categories of the transnational perspective of migration.

The first of these meetings took place in the international colloquium "The transnational city under debate," organized by the Department of Anthropology of the Autonomous Metropolitan University - Iztapalapa Unity -, held in December 2013 in Mexico City. Federico Besserer, Bela Feldman-Bianco and Silvina Merenson participated in this first reunion. Months later, in June 2014, in the $11^{\text {th }}$ Argentinian Congress of Anthropology, Bela Feldman-Bianco, Federico Besserer, Sergio Caggiano and myself shared the symposium "Social anthropology and transnational studies: reflections, dilemmas and (mis) matches." The last meeting, which brought together all the authors in this dossier, was held in the Annual Conference of the Latin American Studies Association (LASA), in New York, in May 2016. On that occasion, the participants of this dossier met in the "Transnational studies and social anthropology: reflections, debates and (mis)matches in the approaches of migratory processes" panel. We presented then the previous versions of the texts that are reunited here and we had a productive discussion enriched, in addition, by the comments, questions and criticisms of the audience. 
As this journey makes visible, the dossier gives continuity to a series of exchanges initiated in different academic instances, recovering its transversal debates and its general objectives. On the one hand, the texts reunited here have in common the objective of submitting to debate the contributions and criticisms reproduced, based on the dialogues undertaken, on the approaches to migration processes. On the other hand, these debates are inspired by an anthropological perspective that structures and guides them.

Since the 1990s, anthropology has made a series of theoretical, empirical and methodological contributions to understanding the economic, social, political and cultural processes involved in the dynamics that go beyond the borders of nation-states. These debates put in evidence that the local, regional, national and global spaces are not already given, but categories that must be investigated as social facts, as constructed and debatable. Rethinking the transnational perspective from social anthropology results in a fundamental exercise, among other things, due to the particularities - the disciplinary archetypes, as Gupta and Ferguson (1997) said - that make up the classical anthropological episteme, constructed from fictions about the correspondence between culture, territory and community space.

But the works of the dossier also share an axis of questioning: How to study these mobilities in Latin America today, including regional dynamics, migrations to Europe and the United States and those that come from other regions? The question is malicious because, to approach it from anthropology, it is necessary to redouble efforts to situationally understand the specific social contexts in which transnational experiences take place. This implies, in turn, a concern with the historical processes that endow these spaces with form and movement; as well as a concern with the different scales (micro, meso and macro) from which social phenomena can be read. The dossier that we present gathers texts based on research about south-north migrations and trajectories, but also those interested in displacements and migratory trajectories between Latin American countries.

This distinction is not minor, since it implies considering that the potentialities and limitations of the dialogues between transnational studies and social anthropology are crossed by the existing asymmetries or shared histories between the actors and nation-states involved in each case. Unlike the distances between the processes and histories corresponding to the United States, Portugal and Mexico, countries like Peru, Bolivia, Chile, Argentina and Uruguay lived or recognize the contemporaneity of state terrorism and the horror of transnational repressive coordination as was the "Condor Plan." At the same time, the transitions to democracy reciprocally strengthened regional institutional, political and social networks. Read together and in this key, the texts gathered here can guide questions and reflections that place the historicity of flows and asymmetries as a crucial analytical dimension to map the 
interconnections between different layers of global, regional and local processes (Feldman-Bianco 2009).

Finally, a last axis of this dossier refers to the fact that, although the empirical material is a fundamental reference, our central proposal is to articulate the dialogue between texts that transcend the case-studies in order to propose different theoretical and/or methodological reflections regarding the connections between transnational studies and social anthropology. These reflections could foster the development of broader theoretical approaches in social sciences regarding the ways in which different sectors, actors and institutions of the global society have internationalized their actions and ways of life.

The aforementioned aspects are found, in different degrees and in different ways, in the articles that compose the dossier. Given that each one presents a particular imprint, it is convenient to return succinctly, to their specificities.

\section{THE DOSSIER}

In the first article, "Transnational studies twenty years later: a story of encounters and dis-encounters," Federico Besserer offers a critical overview articulated by his own research trajectory, through his experience of two decades of studies on transnational migration. In this itinerary, he points out the confrontations between migratory and cultural studies, showing that the interpellation between these fields was more neat and intense than is often recognized. Thus, he points out that the transnational perspective has been constituted from a complex process of approaches and ruptures with trans and interdisciplinary positions. Finally, he explains that the transnational perspective has operated an epistemic break with certain analytical guidelines, which places it in an eminently critical sphere of social thought.

Stephanie Schütze's text, "The emergence of transnational political spaces," leads us to a discussion about the political constitution of transnational social spaces. Attentive to the contradictions between localization and transnationalization of migrant practices, Schütze develops a long-standing ethnography of the political practices of collectives from the Mexican state of Michoacán living in Chicago (United States). She observes how the constitution of a political sphere promoted by these migrant social movements alters the urban conformations, both in Chicago and in the various localities of origin.

Silvina Merenson invites us to the third article of this dossier: "Political community and transnational citizenship: ethnographic perspectives on a heterogeneous articulation." The text takes us, once again, to the debate on transnationalism as a political phenomenon. But here the debate centers on the displacements of meaning and epistemic turns that transnational migratory practices operate in two classic categories of social thought: "political community" and "citizenship." Merenson's reflections come from a dense 
ethnographic research about the experience of Uruguayan migrants in Buenos Aires (Argentina), recovering the contextual and historical transformations that these migrant built as political subjects on both sides of the Rio de la Plata.

The article by Menara Guizardi, "When borders transnationalise people: reframing the migrant transnationalism in the Andean tri-border area," recovers, in its historical-ethnographic dimension, the social networks and practices that interconnect the inhabitants of the border between Chile, Peru and Bolivia. Based on the results of her fieldwork, she discusses the conception that border crossings articulate transnational social fields between origin and destination, driven by a "globalization from below." Regarding the latter, she describes and analyzes the way in which the activities of transboundary inhabitants generate frictions between the local inscription of practices and the transnationalization of knowledge, economies and memories. In a sense similar to that of the song popularized by the Mexican band Los Tigres del Norte, "I did not cross the border, the border crossed me," Guizardi argues that it was not the communities that transnationalized the territories: the borders did so.

Bela Feldman-Bianco closes the dossier with "Anthropology and ethnography: the transnational perspective on migration and beyond." She, as a long time interlocutor of the authors of Nations Unbound (Basch, Glick Schiller and Szanton Blanc 1994), examines critically the transnational perspective on migration and its developments. The article, based upon her ongoing comparative research project on the secular migrations of the Portuguese to New Bedford, MA, USA and São Paulo, Brazil, and the more recent migration of Brazilians to Lisbon, Portugal, indicates the historical conjuncture that led to the formulation of this paradigm, its strengths and limits. Feldman-Bianco looks into the reconfigurations of this paradigm and resulting advances for the study of migrants in cities and, at the same time, argues for the need of a broader notion of migrations and displacements.

\section{REFERENCES}

APPADURAI, Arjun, 1991, "Global ethnoscapes: notes and queries for a transnational anthropology", in Richard Fox (ed.), Recapturing Anthropology: Working in the Present. Santa Fe, School of American Research Press, 191-210.

BASCH, Linda, Nina GLICK SCHILLER, and Cristina SZANTON BLANC, 1994, Nations Unbound. London, Routledge.

BESSERER, Federico, 2004, Topografías Transnacionales: Hacia Una Geografía de la Vida Transnacional. México, DF, Plaza y Valdés Editores. 
FELDMAN-BIANCO, Bela, 2009, "Reinventando a localização: globalização heterogênea, escala da cidade e a incorporação desigual de migrantes transnacionais”, Horizontes Antropológicos, 31: 19-50.

GLICK SCHILLER, Nina, Linda BASCH, and Cristina BLANC-SZANTON, 1992, "Transnationalism: a new analytic framework for understanding migration", Annals of the New York Academy of Sciences, 645 (1): 1-24.

GUIZARDI, Menara, et al., 2015, “Condensaciones en el espacio hiperfronterizo: aproximaciones migrantes en la frontera de Chile”, in Menara Guizardi (ed.), Las Fronteras del Transnacionalismo: Límites y Desbordes de la Experiencia Migrante en el Centro y Norte de Chile. Santiago, Ocholibros, 224-257.

GUPTA, Akhil, and James FERGUSON, 1997, “Discipline and practice: 'the field' as site, method, and location in anthropology", in Akhil Gupta and James Ferguson (eds.), Anthropological Locations: Boundaries and Grounds of a Field Science. Berkeley, University of California Press, 1-47.

HARVEY, David, 1989, The Conditions of Post-Modernity: An Inquiry into the Origins of Cultural Change. Oxford, Blackwell.

LEVITT, Peggy, and Nina GLICK SCHILLER, 2004, “Conceptualizing simultaneity: a transnational social field perspective on society”, International Migration Review, 38 (3): 1002 $-1039$.

MASSEY, Douglas, et al., 1993, "Theories of international migration: a review and appraisal”, Population and Development, 19 (3): 431-466.

MASSEY, Douglas, Luin GOLDRING, and Jorge DURAND, 1994, "Continuities in transnational migration: an analysis of nineteen Mexican communities", The American Journal of Sociology, 99 (6): 1492-1533.

MEREnSON, Silvina, 2016, Los Peludos: Cultura, Política y Nación en los Márgenes del Uruguay. Buenos Aires, Gorla.

MOCTEZUMA, Miguel, 2008, “Transnacionalidad y transnacionalismo”, Papeles de Población, 57: 39-54.

PORTES, Alejandro, 2000, "Social capital: its origin and applications in modern sociology", in E. L. Lesser (ed.), Knowledge and Social Capital: Foundations and Applications. Woburn, Butterworth-Heinemann, 43-57.

PORTES, Alejandro, 2003, “Theoretical convergencies and empirical evidence in the study of immigrant transnationalism”, International Migration Review, 37 (3): 874-892.

PORTES, Alejandro, Luis Eduardo GUARNIZO, and William J. HALLER, 2002, "Transnational entrepreneurs: An alternative form of immigrant economic adaptation", American Sociological Review, 67 (2): 278-298.

PORTES, Alejandro, Luis Eduardo GUARNIZO, and Patricia LANDOLT, 1999, "The study of transnationalism: pitfalls and promise of an emergent research field", Ethnic and Racial Studies, 22 (2): 217-237.

SASSEN, Saskia, 2010, Territorio, Autoridad y Derechos: De los Ensamblajes Medievales a los Ensamblajes Globales. Buenos Aires, Katz. 